\title{
PENENTUAN SIFAT FISIK KENTANG (Solanum tuberosum L.): SPHERICITY, LUAS PERMUKAAN VOLUME DAN DENSITAS
}

\author{
Mustofa $^{1)}$ \\ 1) Program Studi Mesin dan Peralatan Pertanian, Politeknik Gorontalo
}

\begin{abstract}
ABSTRAK
Kentang merupakan salah satu bahan produk pertanian yang banyak dimanfaatkan oleh masyarakat dengan berbagai olahan. Kualitas kentang ditentukan berdasarkan karakteristik fisik, mekanik dan kimia yang berkaitan dengan komposisinya. Karakteristik fisik merupakan aspek penting dalam penanganan bahan pertanian seperti pemisahan, grading, pengangkutan, penyimpanan dan pengolahan. Penanganan dan pengolahan kentang bergantung pada sifat-sifatnya. Disamping itu, sifat fisik bahan pertanian juga merupakan faktor penting dalam perancangan suatu alat pengolahannya. Hal ini berkaitan dengan ukuran dan bentuk, volume, densitas, dan sifatsifat fisik lainnya. Penelitian ini dilakukan untuk mengetahui beberapa sifat fisik kentang. Penentuan ukuran dan bentuk seperti sphericity yang dapat diukur menggunakan jangka sorong dan beberapa persamaan matematis. Sedangkan volume dan densitasnya diukur menggunakan gelas kimia dan penentuan massa dari suatu bahan serta menggunakan persamaan matematis umum. Hasil penelitian menunjukkan bahwa kentang memiliki sphericity, luas permukaan, volume, dan densitas masing-masing adalah $0,86,27,75 \mathrm{~cm} 2,118,40 \mathrm{~cm} 3$, dan $1,01 \mathrm{gr} / \mathrm{mL}$. Perbedaan volume menghasilkan perbedaan densitasnya dimana densitas kentang untuk volume yang berbeda masing-masing adalah 1,01 g.cm-3 dan 1,08 g.cm-3. Oleh karena itu, perancangan suatu alat dalam penanganan dan pengolahan kentang harus didasarkan pada sifat dan karakteristik dari kentang tersebut.
\end{abstract}

Kata Kunci: sphericity, luas permukaan, volume, densitas, kentang

\section{DETERMINING THE PHYSICAL PROPERTIES OF POTATO (Solanum tuberosum L.): SPHERICITY, WIDE SURFACE VOLUME AND DENSITY}

\begin{abstract}
Potatoes are one of the ingredients of agricultural products that are widely used by people with a variety of preparations. Potato quality is determined based on physical, mechanical and chemical characteristics related to its composition. Physical characteristics are important aspects in handling agricultural materials such as separation, grading, transportation, storage and processing. The handling and processing of potatoes depends on their properties. In addition, the physical nature of agricultural materials is also an important factor in the design of a processing tool. This relates to the size and shape, volume, density, and other physical properties. This research was conducted to find out some physical properties of potatoes. Determination of size and shape such as sphericity that can be measured using calipers and some mathematical equations. While the volume and density are measured using a beaker and determining the mass of a material and using general mathematical equations. The results showed that potatoes had sphericity, surface area, volume, and density respectively $0.86,27.75 \mathrm{~cm} 2,118.40 \mathrm{~cm} 3$ and $1.01 \mathrm{gr} / \mathrm{mL}$. The difference in volume produces a difference in density where the density of potatoes for different volumes is $1.01 \mathrm{~g} . \mathrm{cm}-3$ and $1.08 \mathrm{~g} . \mathrm{cm}-3$, respectively. Therefore, the design of a tool in the handling and processing of potatoes must be based on the nature and characteristics of these potatoes.
\end{abstract}

Keywords: sphericity, surface area, volume, density, potatoes 


\section{PENDAHULUAN}

Kentang (Solanum tuberosum L.) merupakan salah satu jenis umbi-umbian yang memiliki kandungan karbohidrat, protein, dan senyawa bioaktif seperti enzim digestif, polifenol, glikoalkaloid, vitamin dan lainnya (Sadowska, dkk., 2004). Produksi kentang dengan kualitas tertentu sangat dipengaruhi oleh beberapa faktor seperti penggunaan umbi kentang yang berkualitas dan layak tanam, kondisi lahan, iklim, cuaca, dan teknik budidaya yang dilakukan (Amarullah, dkk., 2019).

Kentang umumnya ditanam di lahan yang memiliki dataran tinggi dengan iklim dingin seperti daerah pegunungan. Di Indonesia hasil produksi kentang (ton/ha) tahun 2018 berasal dari Jawa Timur dan Jawa Barat yang masing-masing sebanyak 23,37 dan 21,73 ton/ha, sedangkan Gorontalo bukan merupakan daerah penghasil kentang. Kentang di Gorontalo berasal dari Sulawesi Utara yang pada tahun 2018 menghasilkan kentang sebesar 11,34 ton/ha (Badan Pusat Statistik, 2018). Hal ini karena daerah Sulawesi Utara merupakan daerah yang masih tergolong cocok untuk tanaman kentang. Oleh karena disupply dari Sulawesi Utara maka membutuhkan penangan yang baik terutama dalam pengangkutan dan dsitribusi serta penyimpanannya.

Penanganan dan pengolahan produkproduk pertanian dapat berupa pemisahan dan grading, pengemasan dan metode penyimpanan. Proses-proses ini umumnya yang digunakan untuk menentukan harga jual dari produk pertanian tersebut. Sebagai contoh kentang yang memiliki ukuran besar tentu memiliki massa yang berbeda dengan kentang yang berukuran kecil. Hal ini akan berpengaruh pada perbedaan harga jual dimana kentang yang ukurannya besar umummnya lebih mahal dibandingkan dengan yang ukurannya kecil. Untuk skala kecil, misal untuk sekedar kebutuhan rumah tangga, aspek ini tidak memiliki pengaruh yang signifikan. Tetapi untuk skala yang besar sangat berpengaruh pada kuantitas kentang yang diperjual belikan, terutama jika kentang yang ukurannya berbeda dianggap sama sehingga nilai jualnya pun tidak sesuai. Oleh karena itu diperlukan data dan informasi mengenai karakteristik dari produk-produk pertanian. Hal ini dimaksudkan agar memudahkan dalam penanganan dan pengolahannnya.
Berdasarkan uraian di atas, beberapa karakteristik fisik yang akan ditentukan diantaranya berkaitan dengan ukuran dan bentuk (sphericity), luas permukaan, volume, dan densitasnya.

\section{TINJAUAN PUSTAKA}

\section{Kentang}

Tanaman kentang memiliki nama latin Solanum tuberosum $\mathrm{L}$ merupakan umbi yang dapat terbentuk dari batang atau struktur modifikasi batang, seperti geragih atau stolon dan rimpang. Tanaman kentang dapat memunculkan tunas beserta akar, sehingga sering kali dapat dijadikan bahan perbanyakan vegetatif oleh para petani. Kentang juga termasuk dalam kategori tanaman sayuran semusim yang memiliki banyak varietas dan berumur pendek (Samadi, 1997).

\section{Klasifikasi}

Kentang memiliki klasifikasi sebagai berikut (Rukmana, 1997):

$\begin{array}{ll}\text { Kingdom } & \text { : Plantae (tumbuh-tumbuhan) } \\ \text { Divisio } & : \text { Spermatophyta (tumbuhan berbiji) } \\ \text { Subdiviso } & : \text { Angiospermae (Berbiji tertutup) } \\ \text { Clasis } & : \text { Dycotiledone (berkeping dua) } \\ \text { Ordo } & : \text { Solanes } \\ \text { Familia } & : \text { Solanaceae } \\ \text { Genus } & : \text { Solanum } \\ \text { Spesies } & : \text { Solanum tuberosum Linn }\end{array}$

\section{Anatomi Kentang}

(Rukmana, 1997):

kentang terdiri dari

1. Daun. Umumnya daun tanaman kentang rimbun dan memiliki helai daun berbentuk poling atau bulat lonjong dengan ujung meruncing.

2. Batang. Batang kentang dapat berbentuk segi empat atau segi lima tergantung pada varietasnya. Selain itu, batang kentang memiliki ciri-ciri berbuku-buku, berongga, dan tidak berkayu.

3. Akar. Kentang memiliki dua sistem perakaran, yakni tunggang dan serabut. 
4. Bunga. Bunga kentang berkelamin dua (hermaphroditus) yang tumbuh pada ujung batang dan memiliki warna yang bervariasi seperti putih, merah dan biru.

5. Umbi. Umbi kentang memiliki morfologi yang bervariasi ditinjau dari bentuk umbi, warna kulit, warna daging, dan mata tunas.

\section{Syarat Tumbuh Kentang}

Beberapa syarat agar kentang dapat tumbuh antara lain (Samadi, 1997 dan Rukmana, 1997):

a. Lahan tanam berada di daerah dengan dataran tinggi atau daerah pegunungan (1000-3000 mdpl) atau pada dataran medium (300-700 mdpl).

b. Bersuhu rendah (dingin) dengan suhu rata-rata harian $15-20{ }^{\circ} \mathrm{C}$.

c. Kelembaban udara $80-90 \%$ cukup mendapat sinar matahari.

d. Curah hujan antara 200-300 mmper bulan.

e. Suhu optimum pembentukan umbi normal sekitar $15-18^{\circ} \mathrm{C}$.

f. Karakteristik tanah adalah subur, gembur, banyak mengandung bahan organik, aerasi dan drainase yang baik dengan $\mathrm{pH}$ tanah sekitar 56,5 .

\section{METODE PENELITIAN}

\section{Bahan}

Kentang yang digunakan merupakan kentang yang diambil secara acak dari salah satu pedagang sayur di Pasar Sentral Gorontalo sebanyak 10 buah.

\section{Diagram Alir}

Sifat fisik kentang yang diidentifikasi seperi dimensi (sphericity dan roundness), massa, luas permukaan, volume, dan densitasnya. Pengukuran dimensi kentang menggunakan jangka sorong. Massa tiap-tiap kentang diukur menggunakan timbangan digital dengan akurasi 0,1 gram.

Untuk spericity kentang dapat ditentukan menggunakan persamaan (1) (Sahin dan Sumnu, 2006):

$$
\Phi=\frac{(a b c)^{1 / 3}}{a}
$$

dimana $a, b$, dan $c$ masing-masing merupakan diameter mayor, intermediet, dan minor (Gambar 1). Berdasarkan nilai $a, b$, dan $c$, luas permukaan kentang dapat ditentukan menggunakan persamaan (2) dan (3) (Mohsenin, 1970):

$$
\begin{aligned}
& D_{g}=(a b c)^{1 / 3} \\
& A=\pi\left(D_{g}\right)^{2}
\end{aligned}
$$

dimana $\mathrm{D}_{\mathrm{g}}$ dan A masing-masing adalah diameter rata-rata geometris dan luas permukaan.
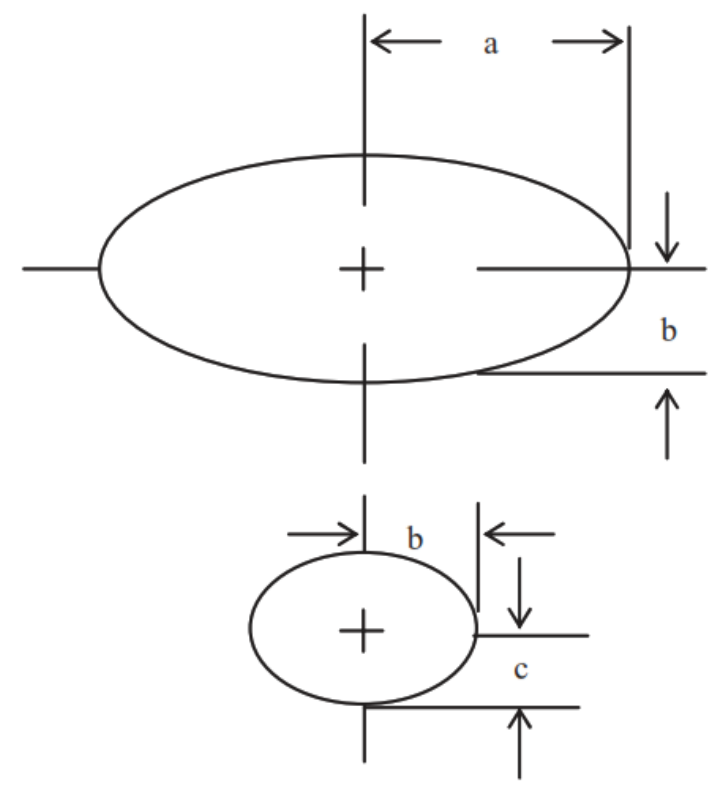

Gambar 3.1. Geometri Elips Triaksial (Sahin dan Sumnu, 2006)

Pengukuran volume kentang dapat dilakukan dengan dua cara. Pertama, kentang diasumsikan berbentuk elips triaksial maka volume kentang dapat ditentukan menggunakan persamaan (4) (Sahin dan Sumnu, 2006):

$V_{e}=\frac{4}{3} \pi a b c$

Kedua, volume kentang dapan ditentukan dengan metode perpindahan air (water displacement method) yang selanjutnya dirumuskan ke dalam persamaan (5):

(5) 
dimana $\mathrm{Vb}$ adalah volume bahan yang diukur; Vakhir adalah volume cairan setelah dimasuki bahan, dan Vawal adalah volume cairan sebelum dimasuki bahan.

Untuk menentukan densitas (massa jenis) kentang digunakan persamaan (6):

$\rho=\frac{m}{V}$

dimana $\rho$ adalah massa jenis $\left(\mathrm{g} / \mathrm{cm}^{3}\right), m$ adalah massa $(\mathrm{g})$, dan $V$ adalah volume $\left(\mathrm{cm}^{3}\right)$.

\section{PEMBAHASAN}

Beberapa sifat fisik kentang berdasarkan hasil pengujian dapat dilihat pada Tabel 1

\begin{tabular}{|c|c|c|c|c|}
\hline Sampel & $\begin{array}{c}\mathbf{A} \\
\left(\mathbf{c m}^{2}\right)\end{array}$ & $\begin{array}{c}\mathbf{V} \\
\left(\mathbf{c m}^{\mathbf{3}}\right)\end{array}$ & $\mathbf{\Phi}$ & $\begin{array}{c}\mathbf{p} \\
(\mathbf{g} / \mathbf{c m} 3)\end{array}$ \\
\hline 1 & 30,66 & 140,00 & 0,89 & 1,00 \\
\hline 2 & 24,31 & 95,00 & 0,85 & 1,05 \\
\hline 3 & 26,25 & 110,00 & 0,86 & 1,00 \\
\hline 4 & 25,30 & 105,00 & 0,91 & 1,00 \\
\hline 5 & 25,61 & 115,00 & 0,92 & 0,96 \\
\hline 6 & 28,84 & 120,00 & 0,83 & 1,04 \\
\hline 7 & 31,45 & 145,00 & 0,81 & 1,00 \\
\hline 8 & 24,20 & 94,00 & 0,85 & 1,01 \\
\hline 9 & 30,01 & 135,00 & 0,86 & 0,96 \\
\hline 10 & 30,88 & 125,00 & 0,83 & 1,04 \\
\hline Rerata & $\mathbf{2 7 , 7 5}$ & $\mathbf{1 1 8 , 4 0}$ & $\mathbf{0 , 8 6}$ & $\mathbf{1 , 0 1}$ \\
\hline
\end{tabular}

Sifat fisik kentang yang diidentifikasi pada penelitian ini adalah sphericity, luas permukaan, volume, dan densitas.

\section{Sphericity}

Sphericity merupakan ukuran kebulatan suatu bahan yang didefinisikan sebagai perbandingan antara diameter bola yang mempunyai volume yang sama dengan objek dengan diameter bola terkecil yang dapat mengelilingi objek (Mohsenin, 1970). Sifat ini sangat penting terutama dalam pengukuran dan perhitungan aliran zat padat dan perhitungan perpindahan panas dan massa (Sahin dan Sumnu, 2006). Suatu bahan dikatakan bulat tatkala nilai sphericity sama dengan 1 . Berdasarkan Tabel 1 diketahui bahwa sphericity kentang sekitar 0,86. Nilai ini mendekati 1 sehingga dapat dikatakan kentang memiliki karakteristik yang cukup bulat. Jika ditinjau dari proyeksi pada Gambar 1, kentang termasuk bahan pertanian yang memiliki bentuk elips triaksial dimana nilai $\mathrm{a}>\mathrm{b}>\mathrm{c}$.

Jika dibandingkan dengan varietas lain (Varietas India) nilai ini tidak jauh berbeda. Dua varietas kentang India yaitu varietas Kufri Jyoti dan Kufri Sinduri masing-masing memiliki sphericity $82,45 \pm 9,12$ dan $86,68 \pm 3,25 \%$ (Singh, dkk., 2006). Sedangkan hasil penelitian lain menunjukkan bahwa kentang memiliki nilai sphericity rata-rata sebesar 0,84 (Dalvand, 2011). Berdasarkan nilai tersebut, nilai sphericity kentang dapat disimpulkan berkisar antara 0,84-0,92.

\section{Luas Permukaan}

Luas permukaan permukaan salah satu sifat fisik yang juga berkaitan dengan dimensi atau ukuran dan bentuk. Luas permukaan kentang pada penelitian ini ditentukan berdasarkan persamaan (3). Berdasarkan hasil perhitungan dan Tabel 1 diketahui bahwa kentang memiliki luas permukaan sekitar 27,75 $\mathrm{cm} 2$. Nilai ini sangat jauh berbeda dengan hasil yang lain dimana kentang Iran memiliki luas permukaan sekitar 138,16 cm2 (Dalvand, 2011) sedangkan luas permukaan kentang Varietas India berkisar 13-35 cm2 (Singh, dkk., 2006). Berdasarkan nilai ini dapat diketahui bahwa luas permukaan kentang dipengaruhi oleh jenis dan varietas kentang itu sendiri.

\section{Volume}

Volume kentang pada penelitian ini dapat ditentukan dengan dua metode pengukuran dan perhitungan. Persamaan yang digunakan untuk menentukan volume kentang yaitu persamaan (4) dan (5). Hasil perhitungan tersebut sebagaimana disajikan pada Tabel 2. 
Tabel 2. Hasil Perbedaan Volume Kentang

\begin{tabular}{|c|c|c|}
\hline Sampel & $\mathbf{V b}^{*}\left(\mathbf{c m}^{\mathbf{3}}\right)$ & $\mathbf{V e}{ }^{* *}\left(\mathbf{c m}^{\mathbf{3}}\right)$ \\
\hline 1 & 140,00 & 127,74 \\
\hline 2 & 95,00 & 90,18 \\
\hline 3 & 110,00 & 101,20 \\
\hline 4 & 105,00 & 95,77 \\
\hline 5 & 115,00 & 97,53 \\
\hline 6 & 120,00 & 116,54 \\
\hline 7 & 145,00 & 132,74 \\
\hline 8 & 94,00 & 89,57 \\
\hline 9 & 135,00 & 123,72 \\
\hline 10 & 125,00 & 129,12 \\
\hline Rerata & $\mathbf{1 1 8 , 4 0}$ & $\mathbf{1 0 9 , 8 9}$ \\
\hline
\end{tabular}

\section{Keterangan:}

*) volume kentang yang ditentukan berdasarkan persamaan (4)

**) volume kentang yang ditentukan berdasarkan persamaan (5)

Berdasarkan nilai yang tertera pada Tabel 2 diketahui bahwa penentuan volume kentang berdasarkan dimensi (Ve) memiliki nilai yang lebih rendah dibandingkan dengan penentuan volume berdasarkan volume cairan dalam wadah $(\mathrm{Vb})$. Selisih volume dari keduanya adalah $8,51 \mathrm{~cm} 3$ dengan persentase selisih sebesar 7,19\%.

\section{Densitas}

Selain sifat fisik yang telah disebutkan sebelumnya, densitas merupakan salah satu sifat fisik yang merupakan ukuran kualitas bahan pertanian (Sahin dan Sumnu, 2006). Berdasarkan data volume yang disajikan pada Tabel 2, maka densitas dapat ditentukan dengan persamaan (6). Berdasarkan perbedaan volume tersebut diperoleh perbedaan densitas sebagaimana disajikan pada Tabel 3.

Tabel 3. Perbedaan Densitas Kentang

\begin{tabular}{|c|c|c|}
\hline Sampel & $\begin{array}{c}\mathbf{\rho}^{*} \\
\left(\mathbf{g} / \mathbf{c m}^{\mathbf{3}}\right)\end{array}$ & $\boldsymbol{\rho}^{* *}\left(\mathbf{g} / \mathbf{c m}^{\mathbf{3}}\right)$ \\
\hline 1 & 1,00 & 1,10 \\
\hline 2 & 1,05 & 1,11 \\
\hline 3 & 1,00 & 1,09 \\
\hline 4 & 1,00 & 1,10 \\
\hline 5 & 0,96 & 1,13 \\
\hline 6 & 1,04 & 1,07 \\
\hline 7 & 1,00 & 1,09 \\
\hline 8 & 1,01 & 1,06 \\
\hline 9 & 0,96 & 1,05 \\
\hline 10 & 1,04 & 1,01 \\
\hline Rerata & $\mathbf{1 , 0 1}$ & $\mathbf{1 , 0 8}$ \\
\hline
\end{tabular}

\section{Keterangan:}

*) densitas kentang yang ditentukan berdasarkan $\mathrm{Vb}$

**) densitas kentang yang ditentukan berdasarkan Ve

Nilai densitas kentang untuk pengukuran volume yang berbeda (Tabel 2) masing-masing adalah 1,01 g.cm-3 dan 1,08 g.cm-3. Nilai ini tidak jauh berbeda dengan hasil lain dimana nilai densitas rata-rata kentang Iran sekitar 1,06 g.cm-3 (Dalvand, 2011), sedangkan untuk varietas India seperti Kufri Jyoti dan Kufri Sinduri masing-masing memiliki densitas sekitar 1,18 g.cm-3 dan 1,10 g.cm-3 (Singh, dkk., 2006).

Hasil ini menunjukkan bahwa densitas kentang lebih besar dari densitas air. Hal ini dibuktikan dengan tenggelamnya kentang ketika dimasukkan ke dalam air. Berdasarkan referensi ini juga dapat disimpulkan bahwa nilai densitas yang lebih sesuai ketika ditentukan berdasarkan volume hasil pengukuran dimensi (Ve), yakni sebesar 1,08 g.cm3. Selisih antar kedua densitas tersebut adalah 0,07 dengan persentase selisih sebesar 6,48\%. 


\section{PENUTUP}

\section{Kesimpulan}

Berdasarkan hasil penelitian dapat disimpulkan sebagai berikut:

1. Kentang yang terdapat di salah satu pedagan Pasar Sentral Gorontalo memiliki sifat fisik berupa sphericity, luas permukaan, volume, dan densitas masing-masing adalah 0,86, $27,75 \mathrm{~cm} 2,118,40 \mathrm{~cm} 3$, dan 1,01 g.cm-3.

2. Dua metode pengukuran berbeda berkaitan dengan volume kentang menghasil volume kentang masing-masing $118,40 \mathrm{~cm} 3$ dan $109,89 \mathrm{~cm} 3$.

3. Perbedaan volume menghasilkan perbedaan densitasnya dimana densitas kentang untuk volume yang berbeda masing-masing adalah 1,01 g.cm-3 dan 1,08 g.cm-3.

\section{Saran}

Perlu adanya penelitian tentang sifat fisik lanjutan seperti roundness, bulk density (densitas curah), dan porosity (porositas).

\section{DAFTAR PUSTAKA}

Amarullah, M.R., Sudarsono, dan Amarillis, S., 2019, Produksi dan Budidaya Umbi Bibit Kentang (Solanum tuberosum L.) di Pangalengan, Bandung, Jawa Barat, Bul. Agrohorti, 7(1), 93-99.

Badan Pusat Statistik, 2018, Statistik Tanaman Sayuran dan Buah-buahan Semusim Indonesia, Jakarta: BPS RI.

Dalvand, M.J., 2011, Physical Properties of Potato Tubers CV. Analytic Cultivated in Iran, Vegetables Crops Research Bulletin, (74), 117-128.

Mohsenin, N.N., 1970, Physical Properties of Plant and Animal Materials, New York: Gordon and Breach.
Rukmana, R., 1997, Kentang: Budidayadan Pasca Panen, Yogyakarta: Kanisius.

Sadowska, J., dkk., 2004, Characteristics of Physical Properties of Genetically Modified Potatoes: Mass and Geometric Properties of Tubers, International Agrophysics, (18), 269-276.

Sahin, S., dan Sumnu, S.G., 2006, Physical Properties of Foods, New York: Springer Science.

Samadi, B., 1997, Usaha Tani Kentang, Yogyakarta: Kanisius.

Singh, D.K., Gosmawi, T.K., dan Chourasia, M.K., 2006, Physical Properties of Two Popular Indian Potato Varieties, Journal of Food Process Engineering, (29), 337-348. 